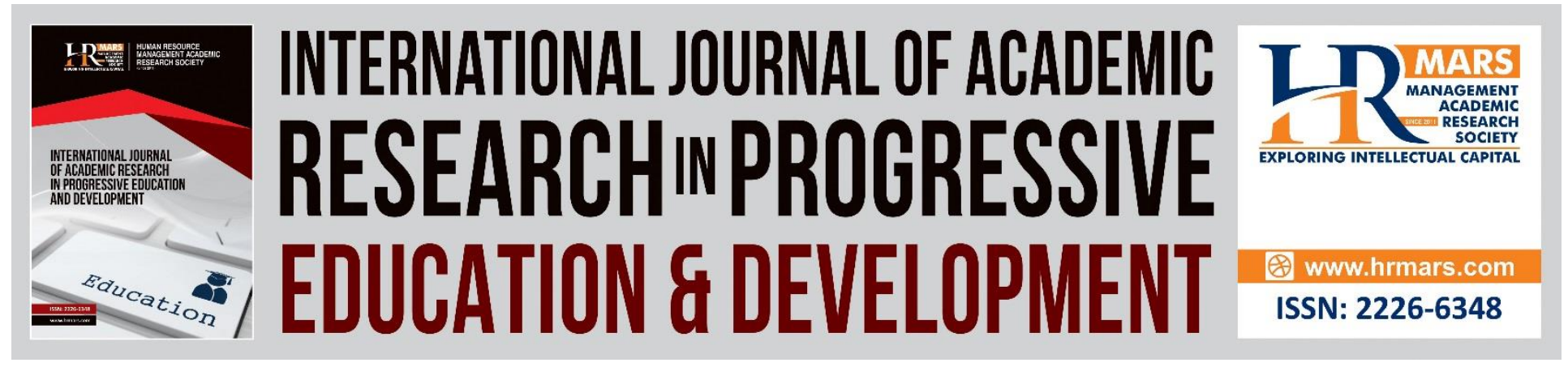

\title{
Identifying Young Learners' Language Learning Strategies in Learning English Vocabulary
}

Catherine Wong Hui Tiing, Chan Poh Phui, Liew Hooi Sieng, Madaline Niek Yai Wen, Sharvini Devi, Harwati Hashim

To Link this Article: http://dx.doi.org/10.6007/IJARPED/v10-i2/10029

DOI:10.6007/IJARPED/v10-i2/10029

Received: 22 March 2021, Revised: 23 April 2021, Accepted: 17 May 2021

Published Online: 25 May 2021

In-Text Citation: (Tiing et al., 2021)

To Cite this Article: Tiing, C. W. H., Phui, C. P., Sieng, L. H., Wen, M. N. Y., Devi, S., \& Hashim, H. (2021). Identifying Young Learners' Language Learning Strategies in Learning English Vocabulary. International Journal of Academic Research in Progressive Education and Development, 10(2), 727-753.

Copyright: (C) 2021 The Author(s)

Published by Human Resource Management Academic Research Society (www.hrmars.com)

This article is published under the Creative Commons Attribution (CC BY 4.0) license. Anyone may reproduce, distribute, translate and create derivative works of this article (for both commercial and non-commercial purposes), subject to full attribution to the original publication and authors. The full terms of this license may be seen

at: http://creativecommons.org/licences/by/4.0/legalcode

Vol. 10(2) 2021, Pg. 727 - 753

http://hrmars.com/index.php/pages/detail/IJARPED

JOURNAL HOMEPAGE

Full Terms \& Conditions of access and use can be found at http://hrmars.com/index.php/pages/detail/publication-ethics 


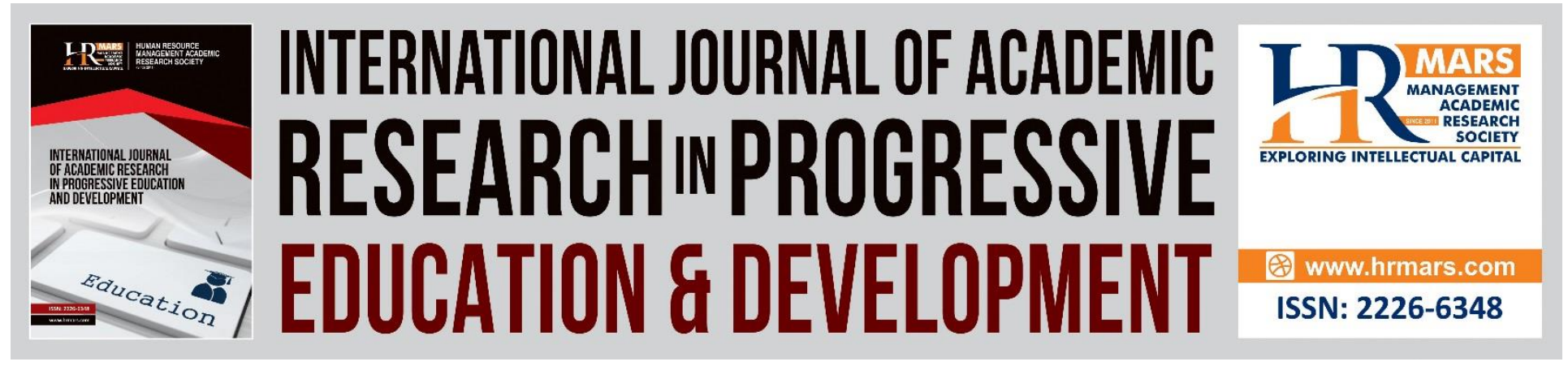

\title{
Identifying Young Learners' Language Learning Strategies in Learning English Vocabulary
}

\author{
Catherine Wong Hui Tiing, Chan Poh Phui, Liew Hooi Sieng, \\ Madaline Niek Yai Wen, Sharvini Devi, Harwati Hashim \\ Faculty of Education, Universiti Kebangsaan Malaysia, Universiti Kebangsaan Malaysia (UKM) \\ Email: huitiing_0523@hotmail.com, pohphui@gmail.com, liewhooisieng@gmail.com, \\ mearamio@gmail.com,m.sharvini@gmail.com, harwati@ukm.edu.my
}

\begin{abstract}
Many theories share the proposition that humans can be categorized according to their learning style and learning strategies. The varieties of learning strategies preference increase the difficulty for an educator to teach an English Second Language Learning (ESL) classroom. Vocabulary is the most important and fundamental aspect of learning a second language. Past studies have shown numerous vocabulary learning strategies (VLS) being investigated on secondary and tertiary level but limited in primary level, as well as taking gender preference into account. Therefore, this study aims to identify the most used language strategies in vocabulary learning and explore the gender differences in the preference of vocab learning strategies among Year 5 pupils in an urban primary school in Malaysia. With the reference of six language learning strategies (LLS) classified by Oxford, a quantitative investigation was conducted using four-point-Likert-scale questionnaires adopted from Perceptual Learning-Style Preference Questionnaire on 40 respondents selected through a purposive sampling. Descriptive statistics is used to analyse the data by calculating the mean. Findings showed that metacognitive is the most used VLS among primary pupils in general and there is an obvious difference in preferences between two genders. Female pupils basically apply more strategies than male pupils and they favour social strategies. Educators should take the preferences of VLS between genders into account when it comes to designing differentiated learning approaches to enhance vocabulary learning in an ESL classroom. Keywords: English as a Second Language (ESL), Language Learning Strategies (LLS), Vocabulary Learning Strategies (VLS), Gender Differences in LLS, Young Learners

\section{Introduction}

In Malaysia, vocabulary learning strategies (VLS) should be notable to consolidate and empower vocabulary learning among primary school pupils. Recently, the use of language learning strategies (LLS) has been increasing to aid pupils in acquiring vocabulary knowledge and skills. LLS has given a great impact on exploring a learner to be a more successful, enjoyable and self-
\end{abstract}


directed person attributed to their behaviors or actions (Oxford \& Nyiko, 1989). This study will discuss various challenges of vocabulary learning strategies (VLS) and Language Learning Strategies (LLS) and its role in facilitating vocabulary learning.

\section{Vocabulary Learning Strategies (VLS) and Language Learning Strategies (LLS)}

Across centuries, vocabulary learning strategies (VLS) have been employed to facilitate vocabulary learning. VLS are regarded as one of the language learning strategies to acquire four fundamental skills namely reading, writing, listening and speaking. As cited in Alahmadi, Shrank \& Foltz (2018), VLS are considered as a sub-class of LLS. Based on O;Malley and Chamot (1990), LLS are utilised to accomplish vocabulary learning tasks. Particularly, there are six language learning strategies (LLS) pertaining to vocabulary learning such as memory, cognitive, compensation, metacognitive, social and affective language learning strategy. Furthermore, LLS describes that a good language learner is based on the frequency of using these strategies. For instance, a learner with effective strategies would apply a few techniques to acquire vocabulary such as "taking deep breath", "using music for relaxation" and "writing a diary" (Roboh \& Tedjaatmadja, 2016). To illustrate, a learner who prefers using reasoning is regarded as a cognitive language learner (Di Carlo, 2017). In other words, LLS is a component which manifests that a good language learner and the choice of using language strategies are inseparable. Hence, the study aims (1) to identify the most used learning strategies among year 5 pupils and (2) to explore the preferred language learning strategies in learning vocabulary by gender.

\section{Barriers of Vocabulary Teaching}

With regard to vocabulary language learning, one of the issues of teaching is the various learning styles among the pupils. In Malaysia, a classroom size (24 feet $\times 30$ feet) has been standardised by Jabatan Kerja Raya (JKR) with 30 pupils and one teacher. Nonetheless, the increasing number of pupils in a classroom every year has been a great challenge to educators, particularly in urban area schools (Ramli, Ahmad \& Masri, 2013). Taking a large classroom size into consideration, educators are responsible to adopt different learning styles in teaching vocabulary. Another barrier that could hinder vocabulary teaching is the multicultural education in our country. In Malaysia, multicultural education has been an integral part of an ESL classroom. Living in a multicultural society, every pupil comes from different backgrounds in terms of language and religion. A finding reveals that teachers' knowledge and attitude towards multicultural education in our country should be paid more attention to ameliorate the situation (Abdullah \& Abdullah, 2018). It explains that the teaching process could be sophisticated when every pupil has their own different mother tongues in acquiring vocabulary. To elaborate, pupils might be greatly influenced by their first language, which could be a hindrance in learning vocabulary effectively. Similarly, gender could be another factor influencing vocabulary learning. Therefore, vocabulary language learning strategies have come to play its role in aiding the learners to realise their learning styles and characteristics in vocabulary learning.

\section{The Role of Language Learning Strategies in Vocabulary Context}

Regarding language learning strategies, it plays a significant role to promote self-directed learning among students (Brown, 2000; Oxford, 2011). Based on their preferences, it stimulates pupils' 


\section{INTERNATIONAL JOURNAL OF ACADEMIC RESEARCH IN PROGRESSIVE EDUCATION AND DEVELOPMENT}

Vol. 10, No. 2, 2021, E-ISSN: 2226-6348 @ 2021 HRMARS

active learning in improving their language skills by employing suitable language strategies. It enables learners to understand their learning styles and learn the language skills independently. By using language learning strategies, it can enhance pupils' thinking skills and problem-solving skills during the learning process. According to Wenden (1987), learners make sense of their learning via language learning strategies. It demonstrates that learners require to store, retrieve and process the information in choosing effective strategies or methods for themselves during the learning process. In this study, taxonomy of language learning strategies is employed to investigate the preferred learning strategies used by year 5 pupils. The following table presents a taxonomy of language learning strategies (Oxford, 1990) which includes direct and indirect language learning strategies:

Table 1: Taxonomy of Language Learning Strategies

\begin{tabular}{|c|c|}
\hline \multicolumn{2}{|l|}{ Direct Strategies } \\
\hline Memory & 1. Creating mental linkages \\
\hline & 2. Applying images and sounds \\
\hline & 3. Reviewing action \\
\hline & 4. Employing action \\
\hline \multirow[t]{4}{*}{ Cognitive } & 1. Practicing \\
\hline & 2. Receiving and sending messages strategies \\
\hline & 3. Analysing and reasoning \\
\hline & 4. Creating structure for input and output \\
\hline \multirow[t]{2}{*}{ Compensation } & 1. Guessing intelligently \\
\hline & 2. Overcoming limitations in speaking and writing \\
\hline \multicolumn{2}{|c|}{ Indirect Strategies } \\
\hline \multirow[t]{3}{*}{ Metacognitive } & 1. Centering your learning \\
\hline & 2. Arranging and planning your learning \\
\hline & 3. Evaluating your planning \\
\hline \multirow[t]{3}{*}{ Affective } & 1. Lowering your anxiety \\
\hline & 2. Encouraging yourself \\
\hline & 3. Taking your emotional temperature \\
\hline
\end{tabular}


Vol. 10, No. 2, 2021, E-ISSN: 2226-6348 @ 2021 HRMARS

\begin{tabular}{|l|l|}
\hline Social & 1. Asking questions \\
\hline & 2. Cooperating with others \\
\hline & 3. Empathising with others \\
\hline
\end{tabular}

\section{Objectives of the Study}

Much attention should be paid to vocabulary learning strategies in the primary school context. In many other countries, related research are used to investigate the effectiveness of vocabulary language learning strategies at secondary, tertiary and undergraduate students : (1) social strategy in Turkish (Baskin, Iscan \& Birol, 2017), (2) compensatory strategy (Mokhtar, Raiwan, Yahaya, Abdullah \& Mohamed, 2017) in Malaysia, (3) the use of VLS based on gender differences (Shadikah, Fauziati \& Supriyadi, 2017) and (4) the use of VLS between high and low vocabulary learners (Ghalebi, Sadighi \& Bagheri, 2021) in Iran. Therefore, the objective of study is (1) to identify the most used learning strategies among year 5 pupils and (2) to explore the preferred language learning strategies in learning vocabulary by gender. The study is guided by two research questions:

1. What is the most used learning strategy by year 5 pupils in learning vocabulary?

2. What is the preferred language learning strategy in learning vocabulary by gender?

\section{Literature Review Vocabulary Learning}

The English language is regarded as an international language around the globe. In Malaysia, English is perceived as one of the most important languages and therefore English is learnt as the second language (Lim et. al, 2021). Learning of English language in Malaysia starts as early as in the primary school where the pupils start getting their formal education in the schools. Government has always paid extra attention pertaining to the issues regarding English language learning in Malaysian classrooms. There are numerous actions taken to make sure Malaysian students excel in acquiring this language so that nobody will leave behind in this era of globalisation. The two crucial actions taken by the government to enhance English language learning is the extension of English learning hours in national secondary schools for a week from 240 minutes to 270 minutes and it is compulsory to pass subject in SPM (Rashid, Abdul Rahman, \& Yunus, 2016). Besides, the implementation of two new programs under 'Uphold Bahasa Melayu (Malay Language) and strengthen the English Language' policy in the Malaysia Education Blueprint 2013-2025, which are the Highly Immersive Programme and the Dual Language Programme (DLP) in year 2016 further proves the governments' concern about the significance of English in Malaysia (Ministry of Education Malaysia, 2013).

According to Jackson and Amvela (2000), vocabulary is a set of words that are utilised in certain circumstances that are known to a person or utilised in a certain coursebook. Vocabulary, according to Richards (2000), is a strong bearer of meaning. In summary, vocabulary may be described as an assortment of words in a language that comprises word forms (spelling and sounds) and word definitions used in various situations to express diverse meanings (Wang, 
2015). Words are the foundation of communication, and a large vocabulary benefits all aspects of communication, including listening, speaking, writing, and reading. The most crucial skill for learning any language is vocabulary because words are used in all languages and it acts as the foundation in learning a language as it is the basic level of learning any language. Grammar components are seeming to be less significant compared to vocabulary because anybody can communicate without remembering or following a set of precise grammar rules, but nobody can communicate without vocabulary (Wilkins, 1972). As stated by Taylor (1990), vocabulary is critical to a language learner and teacher in an English language class, particularly four fundamental language skills.

This demonstrates that, in terms of all language abilities, vocabulary is at the heart of language development. As a result, English vocabulary is the most important language unit for pupils to master at the start of their English studies. Since vocabulary is very crucial in acquiring English language, educators should make sure that the pupils' master this particular component of the language at any cost. No student should leave behind without acquiring sufficient vocabulary knowledge and various vocabulary teaching strategies should be incorporated in ESL classrooms to maximize vocabulary learning.

\section{Language Learning Strategies}

In the context of language acquisition, the term "strategy" is related to a specific type of learner's behaviour modification to improve performance in both using and learning a language (Naiman , Frolich, Stem \& Todesco 1978). Language learning strategies, according to Griffiths (2015), are activities chosen by learners either purposefully or unconsciously for the aim of learning or managing the acquisition of language. Learning methods are described by Rigney (1978, referenced in Saranraj et al., 2016) as a technique that enhances acquisition, retention, retrieval, and performance. Oxford, Lavine, and Crookall (1989, referenced in Hardan, 2013) share similar theories concerning language learning processes as Rigney (1978). As stated by Chang and Liu (2013), learning strategies (LS) are the steps that students take to achieve their learning objectives. Strategic learners are capable of selecting learning ways that will aid their learning, as well as orchestrating the techniques that will best match task needs and their personal learning preferences.

Language Learning Strategies (LLS) are correlated to improving students' language competency (Dissanayaka, 2014). To illustrate, one learning technique may be effective for certain children while failing to be effective for others. The focus is typically on establishing learning strategies, and teachers should be aware of the range of tactics involved in expressing their English knowledge to learners in order to accomplish comprehensive language learning. Teachers and students have focused their efforts not just on 'what to learn,' but also on 'how to learn. Teachers, for example, will be able to adequately lead children using effective language acquisition strategies. However, understanding what learning strategies are is the first step in comprehending this method.

Language learning methods have been given a lot of attention since the 1970s, according to Hardan (2013), because of the critical role they play in language learning. Furthermore, various academics characterised language learning techniques differently depending on how students utilised them to deal with the material they were given and the tactics they utilised. While certain 
strategies are believed to provide the greatest value, others are unsuccessful. According to Chang \& Liu (2013), Oxford's LLS categorization is one of the most complete methods to date. This inventory has been used to collect data for a variety of projects all across the world.

As cited in Oxford (1996), LLS is divided into two main categories and six sub categories mainly memory, cognitive, reward, metacognitive, affective, and social learning strategies. Language learning strategies are categorised into two main aspects which are direct and indirect strategies. As mentioned by Oxford (1996), direct strategies are language learning strategies that directly involve the target language and indirect strategies are language learning strategies that support and manage learning without directly involving the target language. Under direct strategies, there are three sub strategies namely memory, cognitive and compensation strategy whereas under indirect strategy there are another three more sub strategies such as metacognitive strategy, affective strategy and social strategy.

Learners who utilise the memory strategy like to learn by employing images and grouping as it will help them to retain and recall the knowledge that had been learnt (Oxford, 1996). On the other hand, learners who prefer the cognitive method, like recording, practising, and evaluating their experiences. Meanwhile, learners who choose the compensatory route typically utilise speculation and rephrasing tactics to familiarise themselves with the new information. Besides, meta cognitive users appreciate tasks like self-monitoring, concentration, and planning for a mission or project since it helps them recall, perceive, and synthesise what they've learned. The affective method is related to self-encouragement since it consists of learners directing their moods and behaviours appropriately in learning the language. Students that use the social approach like proactively conversing and connecting with their classmates.

As mentioned by Christine and Foong (1997), the reasoning behind learners' strategy research is that if researchers can uncover a list of methods used by successful language learners, then less successful learners may benefit from using those methods in their individual learning. Moreover, good students can turn out to be better by utilising the entire range of techniques that are accessible to them (Naiman et al., 1978). Over the last twenty years, there have been various investigations of learning methodologies utilized by language students. These studies were primarily done to determine what tactics students employ and what factors influence their decisions. A study conducted by Hong-Nam \& Leavell (2006) on ESL students from various cultural backgrounds who enrolled in the Intensive English Program (IEP) discovered that intermediate students recorded higher usage of learning techniques than students at the beginning and advanced levels. According to the findings, students chose to employ metacognitive techniques the most, while using affective and memory techniques the least.

Wong (2005) revealed that preservice teachers with high self-efficacy reported using a greater number of language learning techniques than those with low self-efficacy. Also, the finding manifested that cognitive method is mostly employed by pre-service teachers. Social method and metacognitive method were placed after cognitive method. Compensation and memory methods are stated as less frequently used methods, whereas affective method was noted the least used. In a study examined by Stracke (2016) on Indonesian primary school students, it is exposed that young student used a lot of socio-affective and metacognitive techniques and just a minimal usage of cognitive techniques. Learning with or from others and managing one's own learning were the most desired language learning strategies, while 
memorising terms and practising outside the classroom were the least liked by the young learners.

In addition, a study conducted by Chang and Liu (2013) looks into how EFL university students in Taiwan employ various language learning methods and how it relates to their motivation to learn English. The finding of the study shows that participants with a high degree of English proficiency used considerably more strategies than those with a lower or intermediate level of English proficiency and according to the findings, students with lower English proficiency levels utilised compensation methods the most, whereas students with higher proficiency levels employed metacognitive methods the most. According to a study conducted on gender by El-Dib (2004), the research reveals that the main difference between the two genders in terms of strategic preferences was that male students utilised more social techniques than female students of Sultan Qaboos University (SQU) in Oman.

As reviewed from various past studies, despite the fact that there have been several reports on learner strategy use among ESL or EFL students, it has been difficult to compare these results and conclude which is the best strategy because there there are several factors that contributes to the differences in language learning method such as learning ability, learning environment, race, age, gender, styles of learning, motivation, and beliefs that affect learners' learning strategies (Yang, 2016). Based on the review of several literatures, it can be seen that there are limited studies recorded in the Malaysian content and especially of the primary school pupils. Most of the past studies focus on the language learning strategy used by learners in their tertiary level of either college or university of foreign countries. Besides, most of the studies did not touch upon gender preferences in using selected language learning strategies. The language learning strategies may differ according to the gender as well and it is significant to identify the language learning strategies according to pupils' gender. Therefore, this study focuses on language learning strategies of primary school pupils according to their gender.

\section{Methodology \\ Research Design}

This research employed a quantitative research design. Quantitative research determines relationships between variables and outcomes. Polit and Beck (2012), stated that quantitative research involves the development of a hypothesis - a description of the forecasted result, relationship, or predicted outcome from the research questions. The data are collected objectively through a systematic procedure. A survey is created to collect numerical data in assessing the relationship between the studied variables.

\section{Population and Sampling}

A class of Year 5 pupils in a primary school was chosen based on purposive sampling which is located in the urban area of Kuala Lumpur. The respondents were 40 of them which consisted of 20 boys and 20 girls. According to P. Ur (1996), several aspects contribute to the formation of a heterogeneous class, namely, "language knowledge, cultural background, attitude to the language, mother tongue, intelligence, world knowledge, learning experiences, knowledge of other languages...". The target group was heterogeneous which has different kinds of learners and proficiency level. 
Vol. 10, No. 2, 2021, E-ISSN: 2226-6348 @ 2021 HRMARS

\section{Research Instrument and Procedure}

The survey was conducted online by using Google Form. $100 \%$ of valid responses were gathered by having 40 pupils answering the survey during the Google Meet. In the survey, Perceptual Learning-Style Preference Questionnaire which was designed by Reid (1995) is applied in creating a relevant survey for the data collection. The questionnaire was generated to identify the pupils' preferred learning strategies. The questionnaire consisted of 6 sections with 4 items in each section. The sections included:

Table 2: 6 Sections of Questionnaire

\begin{tabular}{|l|l|}
\hline Section (Table shows respective survey items) & Learning Strategies \\
\hline Section 1 & Memory Strategies \\
\hline Section 2 & Cognitive Strategies \\
\hline Section 3 & Compensation Strategies \\
\hline Section 4 & Metacognitive Strategies \\
\hline Section 5 & Affective Strategies \\
\hline Section 6 & Social Strategies \\
\hline
\end{tabular}

The Likert scale was adapted with 4 scales of Strongly Disagree, Disagree, Agree and Strongly Agree. The participants were asked to show their level of agreement by choosing one scale from 1 to 4.

Before the participants started answering the questionnaire, researchers explained the purposes of the survey and went through the questionnaire with respondents to make sure they understood the meanings of each item. Participants were allowed to ask the meanings of the words they did not know. After that, the link was sent to the participants at the end of the online lesson via Google Meet.

\section{Data Analysis Method}

Descriptive statistics is used to analyse the data gathered. According to Mishra et al. (2019), descriptive statistics are the information which presents the data in the simplest way to describe the basic features of the data. From the collected data, the researchers calculated the means for each item and identified the top preferred learning strategies.

\section{Findings and Discussion}

This section presents the outcomes of the study and discusses the results in relation to the research questions. The results are tabulated according to the scales, 'Strongly Disagree', 
INTERNATIONAL JOURNAL OF ACADEMIC RESEARCH IN PROGRESSIVE EDUCATION AND DEVELOPMENT

Vol. 10, No. 2, 2021, E-ISSN: 2226-6348 @ 2021 HRMARS

'Disagree', 'Agree' and 'Strongly Agree', and it reflects pupils' preference and frequency of language learning strategy.

Table 3: Memory Strategies used by pupils to learn English Vocabulary

\begin{tabular}{|c|c|c|c|c|c|}
\hline $\begin{array}{l}\text { Memory } \\
\text { Strategies }\end{array}$ & $\begin{array}{l}\text { Strongly } \\
\text { Disagree }\end{array}$ & Disagree & Agree & $\begin{array}{l}\text { Strongly } \\
\text { Agree }\end{array}$ & Mean \\
\hline $\begin{array}{l}\text { look at } \\
\text { Pictionary to } \\
\text { learn the new } \\
\text { word. }\end{array}$ & 4 & 10 & 20 & 6 & 2.70 \\
\hline $\begin{array}{l}\text { I read the } \\
\text { words } \\
\text { repeatedly } \\
\text { until } \\
\text { remember } \\
\text { the correct } \\
\text { spelling. }\end{array}$ & 4 & 5 & 17 & 14 & 3.03 \\
\hline $\begin{array}{l}\text { I write the } \\
\text { words for at } \\
\text { least } 5 \text { times } \\
\text { to memorize } \\
\text { the spelling. }\end{array}$ & 3 & 11 & 15 & 11 & 2.85 \\
\hline $\begin{array}{l}\text { I do spelling } \\
\text { for } \\
\text { remembering } \\
\text { the new } \\
\text { vocabulary. }\end{array}$ & 4 & 9 & 17 & 10 & 2.83 \\
\hline
\end{tabular}

Table 3 indicates the memory strategies pupils used in learning English vocabulary. 14 pupils strongly agree that they read the words repeatedly until they remember it. 
INTERNATIONAL JOURNAL OF ACADEMIC RESEARCH IN PROGRESSIVE EDUCATION AND DEVELOPMENT

Vol. 10, No. 2, 2021, E-ISSN: 2226-6348 @ 2021 HRMARS

Table 4: Cognitive Strategies used by pupils to learn English Vocabulary

\begin{tabular}{|c|c|c|c|c|c|}
\hline $\begin{array}{l}\text { Cognitive } \\
\text { Strategies }\end{array}$ & $\begin{array}{l}\text { Strongly } \\
\text { Disagree }\end{array}$ & Disagree & Agree & $\begin{array}{l}\text { Strongly } \\
\text { Agree }\end{array}$ & Mean \\
\hline $\begin{array}{l}\text { I know how to } \\
\text { read prefixes } \\
\text { (eg. un-, dis- } \\
\text {,anti-) and } \\
\text { suffixes (eg - } \\
\text { ly, -ment, - } \\
\text { ness) to } \\
\text { understand } \\
\text { the meaning } \\
\text { of new } \\
\text { words. }\end{array}$ & 7 & 9 & 20 & 4 & 2.53 \\
\hline $\begin{array}{lr}\text { l read } & \text { reabtitles } \\
\text { suf } \\
\text { movies } & \text { to } \\
\text { learn } & \text { new } \\
\text { words. } & \end{array}$ & 2 & 7 & 19 & 12 & 3.03 \\
\hline $\begin{array}{l}\text { I make } \\
\text { sentences } \\
\text { using new } \\
\text { words. }\end{array}$ & 3 & 8 & 21 & 8 & 2.85 \\
\hline $\begin{array}{l}\text { l use } \\
\text { flashcards to } \\
\text { learn new } \\
\text { words. }\end{array}$ & 9 & 17 & 9 & 5 & 2.25 \\
\hline
\end{tabular}

Table 4 displays the cognitive strategies used by the pupils in learning vocabulary. The most frequent cognitive strategies that pupils strongly agree with can assist them in learning new vocabulary. 
INTERNATIONAL JOURNAL OF ACADEMIC RESEARCH IN PROGRESSIVE EDUCATION AND DEVELOPMENT

Vol. 10, No. 2, 2021, E-ISSN: 2226-6348 @ 2021 HRMARS

Table 5: Compensation Strategies used by pupils to learn English Vocabulary

\begin{tabular}{|l|l|l|l|l|l|}
\hline $\begin{array}{l}\text { Compensatio } \\
\text { n Strategies }\end{array}$ & $\begin{array}{l}\text { Strongly } \\
\text { Disagree }\end{array}$ & Disagree & Agree & $\begin{array}{l}\text { Strongly } \\
\text { Agree }\end{array}$ & Mean \\
\hline $\begin{array}{l}\text { I guess the } \\
\text { meanings of } \\
\text { new words. }\end{array}$ & 6 & 14 & 15 & 5 & 2.48 \\
\hline $\begin{array}{l}\text { I use } \\
\text { synonyms to } \\
\text { understand } \\
\text { new words. }\end{array}$ & 4 & 13 & 21 & 2 & 2.53 \\
\hline $\begin{array}{l}\text { I use mimes } \\
\text { or gestures to } \\
\text { understand } \\
\text { new words. }\end{array}$ & 8 & 17 & 11 & 4 & 2.28 \\
\hline $\begin{array}{l}\text { I use other } \\
\text { clues to } \\
\text { understand } \\
\text { the meanings } \\
\text { of new } \\
\text { words. }\end{array}$ & 7 & 7 & 19 & 13 & 3.10 \\
\hline
\end{tabular}

Table 5 exhibits the compensation strategies that the pupils used to learn vocabulary. 13 pupils strongly agreed that using other clues helped them in understanding the meanings of new words. 
INTERNATIONAL JOURNAL OF ACADEMIC RESEARCH IN PROGRESSIVE EDUCATION AND DEVELOPMENT

Vol. 10, No. 2, 2021, E-ISSN: 2226-6348 @ 2021 HRMARS

Table 6: Metacognitive Strategies used by pupils to learn English Vocabulary

\begin{tabular}{|l|l|l|l|l|l|}
\hline $\begin{array}{l}\text { Metacognitiv } \\
\text { e Strategies }\end{array}$ & $\begin{array}{l}\text { Strongly } \\
\text { Disagree }\end{array}$ & Disagree & Agree & $\begin{array}{l}\text { Strongly } \\
\text { Agree }\end{array}$ & Mean \\
\hline $\begin{array}{l}\text { I have a clear } \\
\text { goal in } \\
\text { vocabulary } \\
\text { learning. }\end{array}$ & 0 & 15 & 18 & 7 & 2.80 \\
\hline $\begin{array}{l}\text { I would spend } \\
\text { some time } \\
\text { learning } \\
\text { vocabulary } \\
\text { every day. }\end{array}$ & 2 & 11 & 16 & 11 & 2.90 \\
\hline $\begin{array}{l}\text { I will use } \\
\text { different } \\
\text { strategies to } \\
\text { learn new } \\
\text { vocabulary. }\end{array}$ & 1 & 11 & 22 & 6 & 2.83 \\
\hline $\begin{array}{l}\text { I will learn } \\
\text { from my } \\
\text { mistakes and } \\
\text { find ways to } \\
\text { improve. }\end{array}$ & 3 & 3 & 14 & 20 & 3.28 \\
\hline
\end{tabular}

Table 6 portrays the metacognitive strategies used by the pupils to learn their vocabulary. The most frequent metacognitive strategies used by the pupils are learning from mistakes and spending time learning. 
INTERNATIONAL JOURNAL OF ACADEMIC RESEARCH IN PROGRESSIVE EDUCATION AND DEVELOPMENT

Vol. 10, No. 2, 2021, E-ISSN: 2226-6348 @ 2021 HRMARS

Table 7: Affective Strategies used by pupils to learn English Vocabulary

\begin{tabular}{|l|l|l|l|l|l|}
\hline $\begin{array}{l}\text { Affective } \\
\text { Strategies }\end{array}$ & $\begin{array}{l}\text { Strongly } \\
\text { Disagree }\end{array}$ & Disagree & Agree & $\begin{array}{l}\text { Strongly } \\
\text { Agree }\end{array}$ & Mean \\
\hline $\begin{array}{l}\text { I play soft } \\
\text { music to learn } \\
\text { new words. }\end{array}$ & 6 & 13 & 17 & 4 & 2.48 \\
\hline $\begin{array}{l}\text { I take a deep } \\
\text { breath to } \\
\text { learn new } \\
\text { words. }\end{array}$ & 18 & 11 & 5 & 2.38 \\
\hline $\begin{array}{l}\text { I write down } \\
\text { my feelings in } \\
\text { a diary to } \\
\text { learn new } \\
\text { words. }\end{array}$ & 6 & 17 & 10 & 7 & 2.45 \\
\hline $\begin{array}{l}\text { I discuss my } \\
\text { feelings with } \\
\text { someone } \\
\text { when } \\
\text { learning new } \\
\text { words. }\end{array}$ & 12 & 14 & 5 & 2.38 \\
\hline
\end{tabular}

Table 7 illustrates the affective strategies used by the pupils in learning vocabulary. The most frequent metacognitive strategies used by the pupils are learning from mistakes and spending time learning. 
INTERNATIONAL JOURNAL OF ACADEMIC RESEARCH IN PROGRESSIVE EDUCATION AND DEVELOPMENT

Vol. 10, No. 2, 2021, E-ISSN: 2226-6348 @ 2021 HRMARS

Table 8: Social Strategies used by pupils to learn English

\begin{tabular}{|l|l|l|l|l|l|}
\hline $\begin{array}{l}\text { Social } \\
\text { Strategies }\end{array}$ & $\begin{array}{l}\text { Strongly } \\
\text { Disagree }\end{array}$ & Disagree & Agree & $\begin{array}{l}\text { Strongly } \\
\text { Agree }\end{array}$ & Mean \\
\hline $\begin{array}{l}\text { I ask to slow } \\
\text { down or } \\
\text { repeat the } \\
\text { meaning } \\
\text { when I listen } \\
\text { to new } \\
\text { words. }\end{array}$ & 8 & 22 & 8 & 2.90 \\
\hline $\begin{array}{l}\text { I ask teachers } \\
\text { to correct me } \\
\text { if I make } \\
\text { mistakes in } \\
\text { learning new } \\
\text { words. }\end{array}$ & 4 & 9 & 21 & 6 & 2.73 \\
\hline $\begin{array}{l}\text { I like to } \\
\text { practice new } \\
\text { words with } \\
\text { other } \\
\text { students. }\end{array}$ & 3 & 10 & 17 & 6 & \\
\hline $\begin{array}{l}\text { I ask for help } \\
\text { from peers } \\
\text { and teachers } \\
\text { when } \\
\text { encounter } \\
\text { new words. }\end{array}$ & 1 & 9 & & & \\
\hline
\end{tabular}

Table 8 shows the social strategies used by the pupils in learning vocabulary in which they learn new words from asking peers and teachers. 
INTERNATIONAL JOURNAL OF ACADEMIC RESEARCH IN PROGRESSIVE EDUCATION AND

DEVELOPMENT

Vol. 10, No. 2, 2021, E-ISSN: 2226-6348 @ 2021 HRMARS

Table 9: Language Learning Strategies with Mean Score

\begin{tabular}{|l|l|l|}
\hline No. & Language Learning Strategies & Mean \\
\hline 1 & Memory & 2.85 \\
\hline 2 & Cognitive & 2.67 \\
\hline 3 & Compensation & 2.60 \\
\hline 4 & Metacognitive & 2.96 \\
\hline 5 & Affective & 2.42 \\
\hline 6 & Social & 2.87 \\
\hline
\end{tabular}

The mean for each of the six language learning strategies is signified in Table 9. Among the six strategies, metacognitive strategy is mostly used by year 5 pupils according to the outcomes of the questionnaire, with a mean score of 2.96. It followed by social strategy and memory strategy recorded 2.87 and 2.85 respectively. Affective strategy has the lowest rank with a mean score of 2.42. Metacognitive strategy is mostly employed by pupils to learn vocabulary as the pupils are self-directed learners. This strategy allows them to plan, monitor, evaluate and reflect on their learning process.

Table 10: Mean Score for Metacognitive Strategy

\begin{tabular}{|l|l|l|}
\hline Language Learning Strategy & Items & Mean \\
\hline \multirow{5}{*}{ Metacognitive Strategy } & $\begin{array}{l}\text { I have a clear goal in } \\
\text { vocabulary learning. }\end{array}$ & 2.80 \\
\cline { 2 - 3 } & $\begin{array}{l}\text { I would spend some time } \\
\text { learning vocabulary every } \\
\text { day. }\end{array}$ & 2.90 \\
\cline { 2 - 3 } & $\begin{array}{l}\text { I will use different strategies } \\
\text { to learn new vocabulary. }\end{array}$ & 2.83 \\
\cline { 2 - 3 } & $\begin{array}{l}\text { I will learn from my mistakes } \\
\text { and find ways to improve. }\end{array}$ & 3.28 \\
\hline
\end{tabular}

Table 10 implies the mean score for each item in the metacognitive strategy which Year 5 pupils prefer the most in learning vocabulary. The constructs under metacognitive strategy are as stated below: (1) I have a clear goal in vocabulary learning, (2) I would spend some time learning vocabulary every day, (3) I will use different strategies to learn new vocabulary and (4) I will learn from my mistakes and find ways to improve. Each item received a mean score of 2.80, 2.90, 2.83 and 3.28. 


\section{Research Question 1}

\section{The most used learning strategy by young learners in learning vocabulary}

According to the questionnaire findings, metacognitive strategy is mostly implemented by Year 5 pupils in learning vocabulary. Among the four items listed under metacognitive strategy, most pupils agreed that they learnt from their mistakes and found ways to improve. Pupils had an inclination to apply metacognitive strategies in learning vocabulary as they were self-regulated learners and were aware of their learning.

Inclusive Schools Network (2015) referred metacognitive strategies as methods that assisted pupils to think about their thinking and comprehend the way they learn. Anderson (2002) divided metacognitive strategies into five constituents: planning, selecting, monitoring, regulating and evaluating. Application of metacognitive strategies lead to insightful learning as it combines thinking and reflective processes. Pupils have a clear goal and vision of what they want to learn, how they can learn it and when to employ the most suitable strategies to learn vocabulary. This is supported by Hacker et al. (2009) who proclaimed that metacognitive strategies enabled pupils to practise self-directed learning and generate strategies to deal with the obstacles they encountered in learning vocabulary.

One common mistake that pupils tend to make in learning vocabulary is overgeneralization. For instance, they thought the prefix 'dis-' means 'not' and they added this prefix simply to any word. By using metacognitive strategies, pupils will reflect on these mistakes and find solutions to rectify the errors. They will think and justify the reasons why prefixes 'dis-' cannot be applied to all the words and find other prefixes that carry the meaning 'not' such as 'ir', 'un' and 'non'. This way assisted pupils to grasp new vocabulary. Other than that, pupils' vocabulary learning is sometimes interfered with by their first language. L1 transfer is viewed as a restriction when acquiring vocabulary in an ESL classroom (Tamer, 2018). Metacognitive strategies help pupils to lessen the negative transfer as they spend time learning to pronounce the new vocabulary.

From this study, most pupils preferred to learn vocabulary using metacognitive strategies as they could oversee the progress, monitor and evaluate their performance on a regular basis. It is suggested that teachers should devise more activities using metacognitive strategies to develop pupils' learning autonomy and assist them to be successful in their learning. 
INTERNATIONAL JOURNAL OF ACADEMIC RESEARCH IN PROGRESSIVE EDUCATION AND DEVELOPMENT

Vol. 10, No. 2, 2021, E-ISSN: 2226-6348 @ 2021 HRMARS

\section{Research Question 2}

The preferred language learning strategies in learning vocabulary by gender

Table 11: Memory Strategies used by pupils to learn English Vocabulary

\begin{tabular}{|c|c|c|c|c|c|c|c|c|}
\hline \multirow{2}{*}{$\begin{array}{l}\text { Memory } \\
\text { Strategies }\end{array}$} & \multicolumn{2}{|c|}{$\begin{array}{l}\text { Strongly } \\
\text { Disagree }\end{array}$} & \multicolumn{2}{|c|}{ Disagree } & \multicolumn{2}{|c|}{ Agree } & \multicolumn{2}{|c|}{ Strongly Agree } \\
\hline & M & $\mathbf{F}$ & M & $\mathbf{F}$ & M & $\mathbf{F}$ & M & $\mathbf{F}$ \\
\hline $\begin{array}{l}\text { look at } \\
\text { Pictionary to } \\
\text { learn the new } \\
\text { word. }\end{array}$ & 1 & 3 & 7 & 3 & 8 & 12 & 4 & 2 \\
\hline $\begin{array}{l}\text { I read the } \\
\text { words for } \\
\text { many times } \\
\text { until } \\
\text { remember } \\
\text { the correct } \\
\text { spelling. }\end{array}$ & 2 & 2 & 3 & 2 & 6 & 11 & 7 & 7 \\
\hline $\begin{array}{l}\text { I write the } \\
\text { words for at } \\
\text { least } 5 \text { times } \\
\text { to memorize } \\
\text { the spelling. }\end{array}$ & 1 & 2 & 6 & 5 & 8 & 7 & 5 & 6 \\
\hline $\begin{array}{l}\text { I do spelling } \\
\text { for } \\
\text { remembering } \\
\text { the new } \\
\text { vocabulary. }\end{array}$ & 2 & 2 & 6 & 3 & 7 & 10 & 6 & 4 \\
\hline Total & 6 & 9 & 22 & 13 & 29 & 40 & 22 & 19 \\
\hline Male & 28 & & & & 51 & & & \\
\hline Female & 22 & & & & 59 & & & \\
\hline Result & 51( & & & & & & & \\
\hline
\end{tabular}


INTERNATIONAL JOURNAL OF ACADEMIC RESEARCH IN PROGRESSIVE EDUCATION AND DEVELOPMENT

Vol. 10, No. 2, 2021, E-ISSN: 2226-6348 @ 2021 HRMARS

Table 11: Cognitive Strategies used by pupils to learn English Vocabulary

\begin{tabular}{|c|c|c|c|c|c|c|c|c|}
\hline \multirow{2}{*}{$\begin{array}{l}\text { Cognitive } \\
\text { Strategies }\end{array}$} & \multicolumn{2}{|c|}{$\begin{array}{l}\text { Strongly } \\
\text { Disagree }\end{array}$} & \multicolumn{2}{|c|}{ Disagree } & \multicolumn{2}{|c|}{ Agree } & \multicolumn{2}{|c|}{ Strongly Agree } \\
\hline & M & $\mathbf{F}$ & $\mathbf{M}$ & $\mathbf{F}$ & $\mathbf{M}$ & $\mathbf{F}$ & $\mathbf{M}$ & $\mathbf{F}$ \\
\hline $\begin{array}{l}\text { I know how to } \\
\text { read prefixes } \\
\text { (eg. un-, dis- } \\
\text {,anti-) and } \\
\text { suffixes (eg -ly, } \\
\text {-ment, -ness) } \\
\text { to understand } \\
\text { the meaning } \\
\text { of new words. }\end{array}$ & 5 & 2 & 6 & 3 & 7 & 13 & 1 & 3 \\
\hline $\begin{array}{l}\text { I read subtitles } \\
\text { of movies to } \\
\text { learn new } \\
\text { words. }\end{array}$ & 2 & 0 & 4 & 3 & 9 & 10 & 5 & 7 \\
\hline $\begin{array}{l}\text { l make } \\
\text { sentences } \\
\text { using new } \\
\text { words. }\end{array}$ & 2 & 1 & 5 & 3 & 9 & 12 & 3 & 5 \\
\hline $\begin{array}{lr}\text { l use } \\
\text { flashcards to } \\
\text { learn new } \\
\text { words. }\end{array}$ & 6 & 3 & 7 & 10 & 4 & 5 & 2 & 3 \\
\hline Total & 15 & 6 & 22 & 19 & 29 & 40 & 11 & 18 \\
\hline Male & 37 & & & & 40 & & & \\
\hline Female & 25 & & & & 58 & & & \\
\hline Result & 40 & & & & & & & \\
\hline
\end{tabular}


INTERNATIONAL JOURNAL OF ACADEMIC RESEARCH IN PROGRESSIVE EDUCATION AND DEVELOPMENT

Vol. 10, No. 2, 2021, E-ISSN: 2226-6348 @ 2021 HRMARS

Table 12: Compensation Strategies used by pupils to learn English Vocabulary

\begin{tabular}{|c|c|c|c|c|c|c|c|c|}
\hline \multirow{2}{*}{$\begin{array}{l}\text { Compensatio } \\
\mathbf{n} \\
\text { Strategies }\end{array}$} & \multicolumn{2}{|c|}{$\begin{array}{l}\text { Strongly } \\
\text { Disagree }\end{array}$} & \multicolumn{2}{|c|}{ Disagree } & \multicolumn{2}{|c|}{ Agree } & \multicolumn{2}{|c|}{ Strongly Agree } \\
\hline & M & $\mathbf{F}$ & M & $\mathbf{F}$ & $\mathbf{M}$ & $\mathbf{F}$ & M & $\mathbf{F}$ \\
\hline $\begin{array}{l}\text { guess the } \\
\text { meanings of } \\
\text { new words. }\end{array}$ & 3 & 1 & 8 & 7 & 6 & 8 & 3 & 4 \\
\hline $\begin{array}{l}\text { I use } \\
\text { synonyms to } \\
\text { understand } \\
\text { new words. }\end{array}$ & 1 & 1 & 10 & 11 & 7 & 6 & 2 & 2 \\
\hline $\begin{array}{l}\text { I use mimes } \\
\text { or gestures to } \\
\text { understand } \\
\text { new words. }\end{array}$ & 1 & 2 & 5 & 6 & 7 & 10 & 7 & 2 \\
\hline $\begin{array}{l}\text { I use other } \\
\text { clues to } \\
\text { understand } \\
\text { the meanings } \\
\text { of new } \\
\text { words. }\end{array}$ & 6 & 6 & 10 & 9 & 4 & 4 & 0 & 1 \\
\hline Total & 11 & 10 & 33 & 33 & 24 & 28 & 12 & 9 \\
\hline Male & 44 & & & & 36 & & & \\
\hline Female & 43 & & & & 37 & & & \\
\hline Result & 36 & & & & & & & \\
\hline
\end{tabular}


INTERNATIONAL JOURNAL OF ACADEMIC RESEARCH IN PROGRESSIVE EDUCATION AND DEVELOPMENT

Vol. 10, No. 2, 2021, E-ISSN: 2226-6348 @ 2021 HRMARS

Table 13: Metacognitive Strategies used by pupils to learn English Vocabulary

\begin{tabular}{|c|c|c|c|c|c|c|c|c|}
\hline \multirow{2}{*}{$\begin{array}{l}\text { Metacognitive } \\
\text { Strategies }\end{array}$} & \multicolumn{2}{|c|}{$\begin{array}{l}\text { Strongly } \\
\text { Disagree }\end{array}$} & \multicolumn{2}{|c|}{ Disagree } & \multicolumn{2}{|c|}{ Agree } & \multicolumn{2}{|c|}{ Strongly Agree } \\
\hline & M & $\mathbf{F}$ & M & $\mathbf{F}$ & M & $\mathbf{F}$ & M & $\mathbf{F}$ \\
\hline $\begin{array}{l}\text { I have a clear } \\
\text { goal in } \\
\text { vocabulary } \\
\text { learning. }\end{array}$ & 0 & 0 & 8 & 8 & 6 & 11 & 5 & 2 \\
\hline $\begin{array}{l}\text { I would spend } \\
\text { some time } \\
\text { learning } \\
\text { vocabulary } \\
\text { every day. }\end{array}$ & 0 & 2 & 6 & 6 & 6 & 10 & 9 & 1 \\
\hline $\begin{array}{l}\text { I will use } \\
\text { different } \\
\text { strategies to } \\
\text { learn new } \\
\text { vocabulary. }\end{array}$ & 1 & 0 & 6 & 5 & 9 & 13 & 3 & 3 \\
\hline $\begin{array}{l}\text { will learn } \\
\text { from my } \\
\text { mistakes and } \\
\text { find ways to } \\
\text { improve. }\end{array}$ & 2 & 1 & 2 & 2 & 8 & 6 & 8 & 11 \\
\hline Total & 3 & 3 & 22 & 21 & 29 & 40 & 25 & 17 \\
\hline Male & 25 & & & & 54 & & & \\
\hline Female & 24 & & & & 57 & & & \\
\hline Result & 54 & & & & & & & \\
\hline
\end{tabular}


INTERNATIONAL JOURNAL OF ACADEMIC RESEARCH IN PROGRESSIVE EDUCATION AND DEVELOPMENT

Vol. 10, No. 2, 2021, E-ISSN: 2226-6348 @ 2021 HRMARS

Table 14: Social Strategies used by pupils to learn English Vocabulary

\begin{tabular}{|c|c|c|c|c|c|c|c|c|}
\hline \multirow{2}{*}{$\begin{array}{l}\text { Social } \\
\text { Strategies }\end{array}$} & \multicolumn{2}{|c|}{$\begin{array}{l}\text { Strongly } \\
\text { Disagree }\end{array}$} & \multicolumn{2}{|c|}{ Disagree } & \multicolumn{2}{|c|}{ Agree } & \multicolumn{2}{|c|}{ Strongly Agree } \\
\hline & M & $\mathbf{F}$ & M & $\mathbf{F}$ & M & $\mathbf{F}$ & M & $\mathbf{F}$ \\
\hline $\begin{array}{l}\text { I ask to slow } \\
\text { down or } \\
\text { repeat the } \\
\text { meaning when } \\
\text { I listen to new } \\
\text { words. }\end{array}$ & 1 & 1 & 4 & 4 & 12 & 10 & 3 & 5 \\
\hline $\begin{array}{l}\text { I ask teachers } \\
\text { to correct me } \\
\text { if I make } \\
\text { mistakes in } \\
\text { learning new } \\
\text { words. }\end{array}$ & 4 & 0 & 4 & 3 & 9 & 12 & 3 & 3 \\
\hline $\begin{array}{lr}\text { l like } & \text { to } \\
\text { practice } & \text { new } \\
\text { words } & \text { with } \\
\text { other } & \\
\text { students. } & \end{array}$ & 2 & 1 & 5 & 4 & 10 & 9 & 3 & 6 \\
\hline $\begin{array}{l}\text { I ask for help } \\
\text { from peers } \\
\text { and teachers } \\
\text { when } \\
\text { encounter } \\
\text { new words. }\end{array}$ & 1 & 0 & 7 & 3 & 5 & 12 & 7 & 5 \\
\hline Total & 8 & 2 & 20 & 14 & 36 & 43 & 16 & 19 \\
\hline Male & & & & & 52 & & & \\
\hline Female & 16 & & & & 62 & & & \\
\hline Result & 52( & & & & & & & \\
\hline
\end{tabular}


INTERNATIONAL JOURNAL OF ACADEMIC RESEARCH IN PROGRESSIVE EDUCATION AND DEVELOPMENT

Vol. 10, No. 2, 2021, E-ISSN: 2226-6348 @ 2021 HRMARS

Table 15: Affective Strategies used by pupils to learn English Vocabulary

\begin{tabular}{|c|c|c|c|c|c|c|c|c|}
\hline \multirow{2}{*}{$\begin{array}{l}\text { Affective } \\
\text { Strategies }\end{array}$} & \multicolumn{2}{|c|}{$\begin{array}{l}\text { Strongly } \\
\text { Disagree }\end{array}$} & \multicolumn{2}{|c|}{ Disagree } & \multicolumn{2}{|c|}{ Agree } & \multicolumn{2}{|c|}{ Strongly Agree } \\
\hline & M & $\mathbf{F}$ & M & $\mathbf{F}$ & M & $\mathbf{F}$ & M & $\mathbf{F}$ \\
\hline $\begin{array}{l}\text { I play soft } \\
\text { music to learn } \\
\text { new words. }\end{array}$ & 4 & 2 & 5 & 8 & 9 & 8 & 2 & 2 \\
\hline $\begin{array}{l}\text { I take a deep } \\
\text { breath to learn } \\
\text { new words. }\end{array}$ & 5 & 2 & 8 & 10 & 5 & 6 & 2 & 2 \\
\hline $\begin{array}{l}\text { write down } \\
\text { my feelings in } \\
\text { a diary to learn } \\
\text { new words. }\end{array}$ & 5 & 1 & 13 & 5 & 1 & 9 & 1 & 5 \\
\hline $\begin{array}{l}\text { I discuss my } \\
\text { feelings with } \\
\text { someone } \\
\text { when learning } \\
\text { new words. }\end{array}$ & 6 & 3 & 7 & 5 & 3 & 11 & 3 & 1 \\
\hline Total: & 20 & 8 & 33 & 28 & 18 & 34 & 8 & 10 \\
\hline Male & 53 & & & & 26 & & & \\
\hline Female & 36 & & & & 44 & & & \\
\hline Result & $26(1$ & & & & & & & \\
\hline
\end{tabular}


INTERNATIONAL JOURNAL OF ACADEMIC RESEARCH IN PROGRESSIVE EDUCATION AND

DEVELOPMENT

Vol. 10, No. 2, 2021, E-ISSN: 2226-6348 @ 2021 HRMARS

Table 16: Ranking of preferred strategy by male and female

\begin{tabular}{|l|l|l|l|l|}
\hline Strategies & \multicolumn{2}{l}{ Male } & \multicolumn{2}{l|}{ Female } \\
\hline & Total number & Rank & Total Number & Rank \\
\hline Memory Strategies & 51 & 3 & 59 & 2 \\
\hline Cognitive Strategies & 40 & 4 & 58 & 3 \\
\hline Compensation Strategies & 36 & 5 & 37 & 6 \\
\hline $\begin{array}{l}\text { Metacognitive } \\
\text { Strategies }\end{array}$ & 54 & 1 & 57 & 4 \\
\hline Social Strategies & & 2 & 62 & 1 \\
\hline Affective Strategies & 26 & 6 & 44 & 5 \\
\hline
\end{tabular}

As a whole, the most preferred language strategies by male pupils are metacognitive strategies whereas female pupils prefer social strategies the most to learn vocabulary. Gender has been viewed as an essential affective variable that influences second language acquisition and performs a crucial part. Viriya (2014) concludes that males and females learn differently from each other. The findings show that female pupils generally apply more strategies in vocabulary learning as compared to male pupils. It could be said that every individual has their own preferred learning strategies to achieve learning objectives. The outcomes of the choice of learning strategies could be another topic to discover in related future research.

\section{Implications and Conclusion}

Vocabulary is the fundamental element of a language as the main four skills, reading, writing, listening and speaking rely on the lexicon derived from vocabulary learning. This study is to identify what is the most used vocabulary learning strategies among primary school ESL pupils. We found that they prefer to apply metacognitive learning strategies to learn vocabulary in a second language. This is because ESL learners usually have prior knowledge on the concept or meaning of a word in their first language. Instead of learning a whole new vocabulary, they are learning how to spell the words and apply the usage of the vocabularies. Pupils have a clear goal and vision of what they want to learn, how they can learn it. They also learn from mistakes and find ways to correct it. This implies educators should boost learners' motivation by helping them set goals as well as guide them to overcome mistakes such as common mistakes due to L1 interference and overgeneralization. Although both male and female pupils prefer metacognitive strategies in general, there are some differences in the VLS preferences between the two genders. We can summarize that female pupils apply more VLS than male pupils as the number of female pupils who agree and strongly agree that they used the VLS in all 6 categories are higher than the number of male pupils. Besides that, female pupils favour social strategies which involve 
interaction with educators and group discussions with peers. This study can be used as a guide for educators to understand better about VLS preferences among primary pupils according to their gender. Thus, they can refer to the findings to design differentiated learning approaches in their ESL classroom accordingly to achieve more effective vocabulary learning.

This research serves as a reminder to educators throughout the world that learners are not the same and differentiated learning is something that is unavoidable by teachers in a language classroom. Even though there are several language learning strategies available today, teachers should play their part to assist the learners to learn the language based on the strategies preferred by the learners. This study can be used as a guide for educators to understand better about VLS preferences among young learners according to their gender. Gender differences should be taken into consideration in applying suitable language learning strategies. An educator should be aware and conscious of young learners' learning styles or preferences for different genders to acquire vocabulary. It is significant for educators to examine young learners' language learning strategies in teaching and learning process. Thus, they can refer to the findings to design differentiated learning approaches in their ESL classroom accordingly to achieve more effective vocabulary learning in the future To summarise, this study opens a new dimension on the issue of language learning strategies and will undoubtedly be significant for both students and teachers in the future, particularly in the teaching of English as a second language.

\section{References}

Abdullah, M. N. L. Y., \& Abdullah, A. C. (2018). Preschool Teachers' Training and Attitudes towards Multicultural Education in Malaysia. International Journal of Early Childhood Education and Care, 7, 1-13.

Alahmadi, A., Shank, C., \& Foltz, A. (2018). Vocabulary learning strategies and vocabulary size: Insights from educational level and learner styles. Vocabulary Learning and Instruction, $7(1), 1-21$.

Anderson, N. J. (2002). The Role of Metacognition in Second Language Teaching and Learning. ERIC Clearinghouse on Languages and Linguistics Washington DC.

Baskin, S., Iscan, A., Karagoz, B., \& Birol, G. (2017). The Use of Vocabulary Learning Strategies in Teaching Turkish as a Second Language. Journal of education and practice, 8(9), 126-134.

Brown, H. D. (2000). Principles of language learning and teaching (Vol. 4). New York: Longman.

Chang, C. H., \& Liu, H. J. (2013). Language Learning Strategy Use and Language Learning Motivation of Taiwanese EFL University Students. Electronic Journal of Foreign Language Teaching, 10(2).

Christine, C. M. G., \& Kwah, P. F. (1997). Hong Kong Journal of Applied Linguistics Volume 2, No. 1, June Chinese ESL Students' Learning Strategies: A Look at Frequency, Proficiency, and Gender'

Di Carlo, S. (2017). Understanding cognitive language learning strategies. International Journal of Applied Linguistics and English Literature, 6(2), 114-126.

Dissanayaka, T. D. (2014). The learning styles and the preferred teaching-learning strategies of first year physiotherapy students. Int J Sci Res Publ, 4(7), 1-3.

El-Dib, M. A. B. (2004). Language learning strategies in Kuwait: Links to gender, language level, 
and culture in a hybrid context. Foreign Language Annals, 37(1), 85-95.

Ghalebi, R., Sadighi, F., \& Bagheri, M. S. (2021). A study of vocabulary learning strategies among high and low Iranian English vocabulary learners. Cogent Education, 8(1), 1834933.

Griffiths, C. (2015). What have we learnt from good language learners? ITT Journal, 69(4), 425-433.

Hacker, D. J., John, D., and Arthur, C. G. (2009.). Handbook of

Metacognitionin EducationHardan, A. A. (2013). Language Learning Strategies: A general Overview. Procedia-Social and Behavioral Sciences, Vol. 106, 1712 - 1726.

Hong-Nam, K., \& Leavell, A. G. (2006). Language learning strategy use of ESL students in an intensive English learning context. System, 34(3), 399-415.

Inclusive School Network. (2015). Metacognitive Strategies. Stetson and Associates, Inc. Jackson, H., \& Amvela, E. Z. (2000). Words, meaning and vocabulary. Trowbridge: The Cromwell Press.

Lim, T. M., Sze, D. W. L., Raki, D., Lim, L. M., Sani, S., \& Hashim, H. (2021). Year 6 Pupils' Language Learning Strategies in Learning English Grammar. International Journal of Academic Research in Business and Social Sciences, 11(4), 1196-1209.

Ministry of Education Malaysia. (2013). Malaysia education blueprint 2013-2025. Putrajaya: Ministry of Education

Mishra, P., Pandey, C. M., Singh, U., Gupta, A., Sahu, C., \& Keshri, A. (2019). Descriptive statistics and normality tests for statistical data. Annals of cardiac anaesthesia, 22(1), 6772. https://doi.org/10.4103/aca.ACA_157_18

Mokhtar, A. A., Rawian, R. M., Yahaya, M. F., Abdullah, A., \& Mohamed, A. R. (2017). Vocabulary learning strategies of adult ESL learners. The English Teacher, 12.

Naiman, N., Frohlich, M., Stern, H. H., \& Todesco, A. (1978). The Good Language Learner. Toronto: Modern Language Centre. Ontario Institute for Studies in Education.

O'malley, J. M., O'Malley, M. J., Chamot, A. U., \& O'Malley, J. M. (1990). Learning strategies in second language acquisition. Cambridge University Press.

Oxford, R., \& Nyikos, M. (1989). Variables Affecting Choice of Language Learning Strategies by University Students.The Modern Language Journal, (3):291-299.

Oxford, R. (1990). Language learning strategies. New York, 3.

Oxford, R. L. (Ed.). (1996). Language learning strategies around the world: Cross-cultural perspectives (No. 13). Natl Foreign Lg Resource Ctr.

Oxford, R. (2011). Teaching and Researching Language Learning Strategies. Harlow: Pearson Education.

Polit, D. F., \& Beck, C. T. (2012). Nursing research: Generating and assessing evidence for nurse.

Ramli, N. H., Ahmad, S., \& Masri, M. H. (2013). Improving the classroom physical environment: Classroom users' perception. Procedia-Social and Behavioral Sciences, 101, 221-229.

Rashid, R. A., Abdul Rahman, S. B., \& Yunus, K. (2016). Reforms in the policy of English language teaching in Malaysia. Policy Futures in Education, 15(1), 100-112.

Reid, J. (1995). Learning Styles in the ESL/EFL Classroom. Boston: Heinle \& Heinle.

Richards, J. C. (2000). Series editor's preface. In N. Schmitt, Vocabulary in language teaching 
(pp. xi-xii). Cambridge: Cambridge University Press.

Rigney, J. W. (1978) Learning Strategies: A Theoretical Perspective. Academic Press, New York.

Roboh, A. G., \& Tedjaatmadja, H. M. (2016). Affective strategies used by high proficiency learners at hand fortuna center. Kata Kita, 4(2), 80-85.

Saranraj, L., Zafar, S., \& Khan, Z. A. (2016). Language Learning Strategies-A Reappraisal. Language Learning, 2278, 0742.

Shadikah, A. A., Fauziati, E., \& Supriyadi, S. (2017). The effect of vocabulary learning strategies on vocabulary mastery based on gender differences. In Proceeding of International Conference on Art, Language, and Culture (pp. 495-505).

Stracke, E. (2016). Language learning strategies of Indonesian primary school students: In relation to self-efficacy beliefs. System, 60, 1-10.

Tamer, M. A., Mansor, N., Talafhah, R. H., \& Jarrah, M. A. (2018). The relationship between metacognitive strategies and other external factors: L1 transfer, motivation and anxiety. Sch. Int. J. Linguist. Lit.; Vol-1, Iss-2, July-August, 43-54

Taylor, L. (1990). Teaching and Learning Vocabulary. New York: Prentice Hal.

Ur, P. A. (1996). Course in Language Teaching: Practice to Theory. Cambridge, Cambridge University Press, 375.

Viriya, C., \& Sapsirin, S. (2014). Gender differences in language learning style and language learning strategies. Indonesian Journal of Applied Linguistics, 3(2), 77-88.

Wang, F. (2015). Constructivism-based mobile application for efl vocabulary learning (Doctoral dissertation, School of Foreign Language. Institute of Social Technology. Suranaree University of Technology).

Wenden, A. (1987). Conceptual background and utility. Learner strategies in language learning, 5, 3-13.

Wilkins, D. A. (1972). Grammatical, Situational and Notional Syllabuses.

Wong, M. S. L. (2005). Language learning strategies and language self-efficacy: Investigating the relationship in Malaysia. RELC journal, 36(3), 245-269.

Yang, X. (2016). Study on factors affecting learning strategies in reading comprehension. Journal of Language Teaching and Research, 7(3), 586-590. 